\title{
Biodegradable polymer nanofiber membrane for the repair of cutaneous wounds in dogs - two case reports
}

\section{Membrana de nanofibras de polímeros biodegradáveis na reparação de feridas cutâneas em cães - relato de dois casos}

\author{
Lívia Gomes Amaral ${ }^{1}$; Emily Correna Carlo Reis ${ }^{2 *}$; Natália Alves Fernandes ${ }^{1}$; \\ Andrea Pacheco Batista Borges ${ }^{2}$; Fabrício Luciani Valente ${ }^{2}$; \\ Rodrigo Viana Sepulveda ${ }^{3}$
}

\begin{abstract}
The study of wound healing and its treatment is extremely important in veterinary medicine due to the high frequency of wounds and the difficulty in treating wounds by second intention. Thus, the objective of this study was to evaluate the use of a nanofiber membrane made of biodegradable polymers as a method of wound treatment in dogs. This study comprised two dogs with bite wounds. Debridement and cleaning was performed followed by the application of the membrane. In one dog, the wound was in the left proximal calcaneal region with clinical signs of infection, necrotic tissue, and muscle and the gastrocnemius tendon were exposed. The wound displayed rapid formation of granulation tissue which became excessive, so it was necessary to debride several times. However, with the suspension of the use of the membrane, formation of this tissue was not observed, and the wound evolved to epithelialization and fast contraction. In the second dog, there was a deep wound on the medial aspect of the proximal right hind limb, with clinical signs of infection, with muscle exposure. Once the membrane was placed, granulation tissue formed, and the membrane was used until the level of this tissue reached the skin. The wound underwent rapid epithelialization and contraction, without developing exuberant granulation tissue. Efficient wound repair was observed and the dogs exhibited greater comfort during application and use of the membrane. More studies should be conducted in dogs focusing on the application of this membrane until the appearance of healthy granulation tissue, as continued use seems to stimulate the formation of exuberant granulation tissue.
\end{abstract}

Key words: Wound healing. Biomaterials. Bandages. Nanotechnology. Canine.

\section{Resumo}

O estudo da reparação e tratamento das feridas cutâneas possui extrema importância em medicina veterinária devido à alta frequência e dificuldade no tratamento por segunda intenção. Este estudo objetivou avaliar o uso da membrana de nanofibras de polímeros biodegradáveis, como alternativa no tratamento de feridas em cães. Foram incluídos no trabalho dois cães com feridas por mordedura. Foi realizado o debridamento e limpeza das feridas e a aplicação da membrana. Em um animal, a ferida em região proximal ao calcâneo esquerdo, apresentava sinais clínicos de infecção, com tecido necrótico, exposição da musculatura e do tendão gastrocnêmio. Foi observada formação rápida de tecido de

\footnotetext{
${ }^{1}$ Médico Veterinário, Discentes do curso de Residência em Medicina Veterinária, Universidade Federal de Viçosa, UFV, Viçosa, MG, Brasil. E-mail: liviagamaral@yahoo.com.br; naty fernandes9@hotmail.com

2 Profs., UFV, Viçosa, MG, Brasil. E-mail: emily.carlo@ufv.br; andrea@ufv.br; fabriciovalente@gmail.com

${ }^{3}$ Médico Veterinário, Discente do Programa de Pós-Graduação em Medicina Veterinária, UFV, Viçosa, MG, Brasil. E-mail: rodrigovianasepulveda@gmail.com

* Author for correspondence
} 
granulação que se tornou exuberante, sendo necessário debridamento seriado. Porém, com a suspensão do uso da membrana a formação desse tecido não foi mais observada, evoluindo para epitelização e rápida contração. No outro animal, a ferida em face medial proximal do membro pélvico direito, era profunda, com sinais clínicos de infecção e musculatura exposta. A formação de tecido de granulação também apresentou-se rápida, utilizando-se a membrana apenas até que o nível deste tecido se igualasse ao da pele, evoluindo para rápida epitelização e contração sem formação de tecido de granulação exuberante. Foi observada reparação eficiente e com maior conforto para os pacientes durante aplicação e utilização da membrana. Acredita-se que mais estudos devam ser realizados focando a aplicação em cães até o aparecimento do tecido de granulação saudável, pois as observações deste estudo indicam possível estimulação do tecido de granulação exuberante com utilização da membrana.

Palavras-chave: Cicatrização de feridas. Biomateriais. Bandagens. Nanotecnologia. Cão.

\section{Introduction}

The skin represents around $24 \%$ of the entire body weight of a puppy and $12 \%$ of the weight of a fully grown dog (PAVLETIC, 1999). It is the barrier against microorganisms and trauma between the body and the environment (ISAAC et al., 2010). The interruption of the continuity of the skin is called a wound, which may be superficial or deep. Traumatic wounds are the most frequent types in dogs and cats; animal bites and vehicle crashes are the main causes, and therefore most of these wounds are infected or occur with great tissue loss (ARIAS et al., 2008).

The skin has two main repair processes: regeneration and scarring. Regeneration can be defined as the replacement of the lesioned tissue by new tissue with the same function and morphology, as long as the basal membrane remains intact. Scarring occurs in response to deeper damage to the skin layer and involves the deposition of a collagen rich tissue with different function and morphology in the dermis and epidermis (GURTNER et al., 2008). The repair process can be divided into three phases: inflammatory/debridement, repair and maturation. This classification is for better understanding and assumes these three phases are sequential, but they can also occur simultaneously in a given wound (PAVLETIC, 1999; ARIAS et al., 2008).

Currently, a great dilemma in human medicine is how to treat wounds in which repair is only possible by second intention, as the patient remains susceptible to important complications such as infection, repair delay and dehydration, among others. These complications also occur in dogs with a complicating factor: a total commitment of the animal's owner is necessary for daily hygiene and wound bandage changes (ARRUDA et al., 2010). Therefore, the use of membranes made of bioresorbable materials is a possible therapeutic option as they can significantly accelerate the repair process. They protect wounds against infections, they have mechanical properties similar to the extracellular matrix and they provide support for fibroblast migration and attachment (PEREIRA et al., 2013; VATANKHAH et al., 2014).

During recent years, tissue engineering has focused on nanotechnology, especially nanofibers, for the development of membranes and other products for skin repair (KONWARH et al., 2013; VATANKHAH et al., 2014). Membranes made of cellulose nanofibers, natural biodegradable polymers, are marketed and frequently used for chronic wounds in human medicine (OLYVEIRA et al., 2014).

The present work reports two cases where cellulose nanofiber membranes were used for the second intention treatment of wounds affecting an extensive area of epidermis and dermis in two dogs. We sought to evaluate the clinical use of this membrane during the wound repair process, aiming at a routine use of this biomaterial in dogs. 


\section{Material and Methods}

\section{Animals}

This study was previously approved by the Ethics Committee on Animal Use of the Universidade Federal de Viçosa, protocol 82/2014. Animals were selected among those taken for medical care at the Veterinary Hospital of the university. For inclusion into the study, the animals were selected based on the characteristics of the wound (extensive and deep wounds with signs of infection in places of delayed repair) and on the owners' commitment to regularly take their dogs for medical care at the institution.

\section{Wound evaluation}

The following clinical variables were analyzed: edema (degree and location), presence of blood and necrotic tissue, crust (presence and features: thin/thick, dry/humid, regular/irregular surface), granulation tissue (presence and color) and fluid (presence and features). Additionally, wound height (longitudinal axis of the limb) and width (limb transversal axis) were measured using a caliper rule. The wound was evaluated until complete repair.

\section{Therapeutic procedures}

When necessary, wounds underwent surgical debridement with abundant rinsing using 1\% polyvinylpyrrolidone in saline solution, always with the animals under general anesthesia (premedication with $0.5 \mathrm{mg} / \mathrm{kg}$ intramuscular morphine, induction with $0.2 \mathrm{mg} / \mathrm{kg}$ intravenous midazolam and $6 \mathrm{mg} / \mathrm{kg}$ intravenous propofol) with propofol boluses for maintenance. Subsequent rinsing was performed only with Lactated Ringer's solution. Antimicrobials were also used: cephalexin (30 $\mathrm{mg} / \mathrm{kg}$ ) every $12 \mathrm{~h}$ for a minimum of $14 \mathrm{~d}$ along with metronidazole $(25 \mathrm{mg} / \mathrm{kg})$ every $12 \mathrm{~h}$ for 5 d. Analgesics included tramadol hydrochloride (6 $\mathrm{mg} / \mathrm{kg}$ ) every $8 \mathrm{~h}$ for at least $3 \mathrm{~d}$ and meloxicam $(0.1 \mathrm{mg} / \mathrm{kg})$ every $24 \mathrm{~h}$ for $3 \mathrm{~d}$. All medications were administered parenterally at the hospital and prescribed orally for home care.

After wound cleaning and debridement, a cellulose nanofiber membrane $\left(\right.$ Nanoskin $\left.^{\circledR}\right)$ was aseptically applied on the wound. It was made using a wet gaze with $0.9 \%$ sterile saline solution for improved adhesion of the membrane. After adhesion, the margins of the membrane were removed with scissors and a bandage with nonadherent gaze was applied, followed by a crepe bandage and tape.

Wounds were evaluated in variable intervals of time, from 1 to $10 \mathrm{~d}$, when cleaning and changes of the membrane were performed as necessary.

\section{Results}

Case 1

The first patient was a male Great Dane, one year old, with a wound proximal to the calcaneus on the left pelvic limb due to a bite from another dog. The accident occurred $7 \mathrm{~d}$ before medical care at the hospital, and the wound appeared infected with significant necrotic tissue, serosanguinous discharge, a thin crust on its borders, a fetid odor and exposure of the gastrocnemius tendon and its muscles (Figure 1A). Edema was noted both proximal and distal to the wound and a weightbearing lameness was also observed. 
Figure 1. Sequential images of the wound on the proximal aspect of the calcaneus of the pelvic left limb of a Great Dane (case 1) during the inflammatory/debridement phase (A and B) and during the repair phase (C), Viçosa, 2014. A: On the first day of treatment necrotic tissue can be noted (arrows) as well as muscle exposure. B: On day 6, healthy granulation tissue was observed, associated with everted margins (arrows). C: On day 34, the wound had exuberant granulation tissue over its entire surface. D, E and F: Sequential images of the wound on the proximal medial surface of the right pelvic limb in a mixed breed male dog (case 2) during granulation (D and E) and epithelization processes (F). D: Wound on day 7 of treatment where granulation tissue and a hematic crust (arrows) can be noted. E: Wound on day 7 of treatment showing application of the membrane. F: Wound on day 22 with granulation tissue up to the level of the adjacent margins and epithelization (arrows). G: granulation. C: crust. T: gastrocnemius tendon.

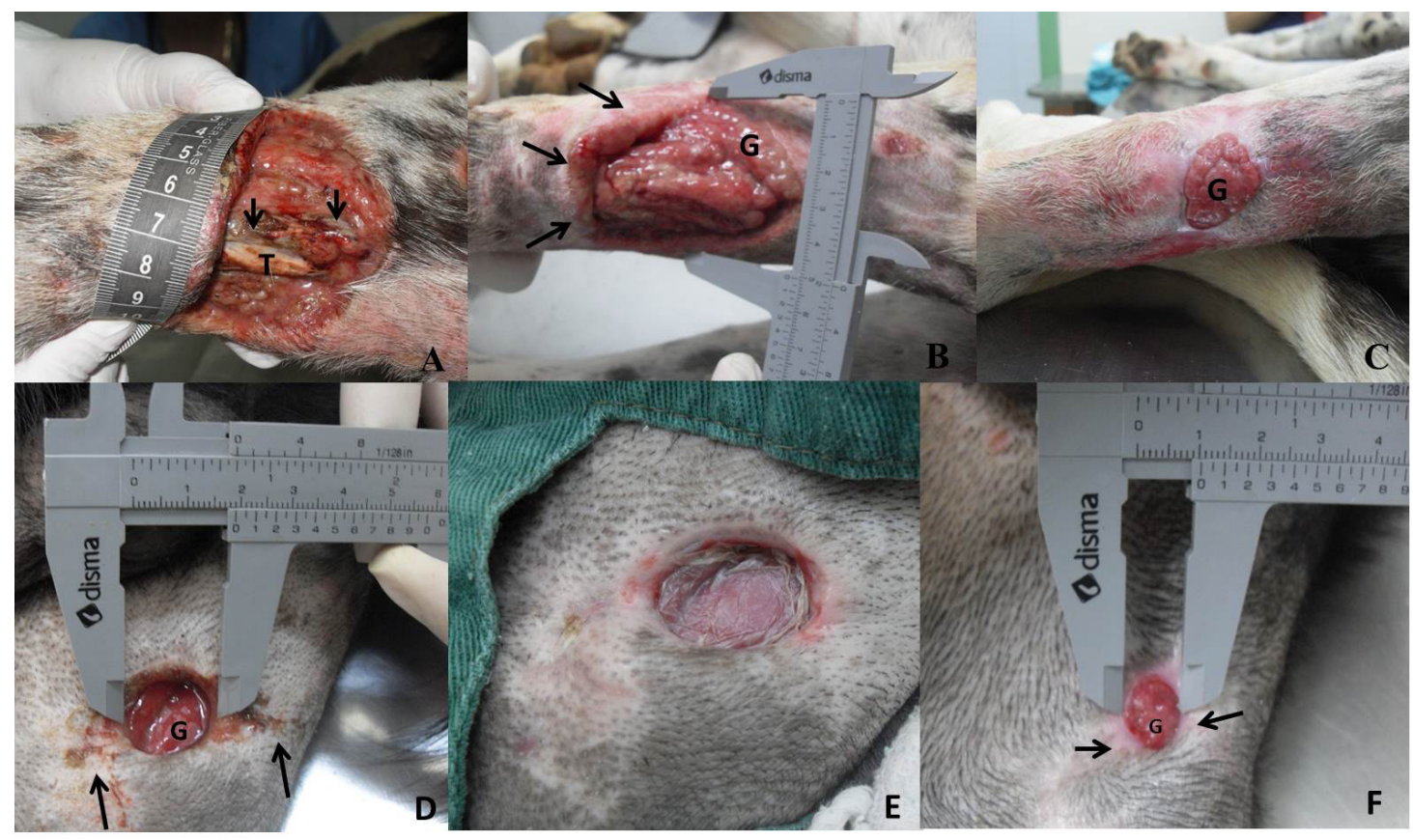

For the first procedure, the animal was anesthetized as previously described for wound rinsing and surgical debridement, followed by membrane application. The wound healed in 51 days, during which time the membrane was changed on days $1,3,6,9,10,12,15,17,23,26$, 28 and 30 (considering the first debridement as day one). During bandage and membrane changes, no chemical restraint was necessary (sedatives nor anesthetics) and manual restraint was also not needed; an assistant just held the limb to make the procedure easier. After 30 days, the wound was left open without a membrane or any bandage, and daily cleaning was performed at home by the owner. The wound was evaluated at 34, 36 and 51 days.
The formation of healthy granulation tissue began at day 6 , but exuberant granulation tissue was observed on days $9,12,15,17,23$ and 34 on the wound margins (Figure 1B). Debridement included removing these margins with a \#10 scalpel blade and routine cleaning. On day 34 the bandage was humid (Figure 1C) with a urine odor, and there was a great amount of exuberant granulation tissue on all wound surfaces and the wound had increased in width. The wound was cleaned and debrided to remove the exuberant granulation tissue down to below the wound margin level. Thereafter, the wound was left open with no membrane or bandage and with daily cleaning at home. Granulation tissue reached the level of the skin by day 36 , and by day 51 , the wound was completely repaired with a very small crust on its center. 


\section{Case 2}

The second patient was a mixed breed male dog, approximately one year old, with a bite wound from a capybara which occurred seven days before first medical care. The wound was on the medial aspect of the proximal right pelvic limb, and it was deep with muscle exposure. The wound was infected, the surrounding subcutaneous tissue was dislocated and the proximal part of the limb was slightly edematous. Initially, surgical debridement was performed along with cleaning with $0.9 \%$ sterile saline solution, and the dog was returned daily for wound cleaning, bandage change and application of an ointment (Vetaglós ${ }^{\circledR}$ ). Five days after initial medical care at the hospital, treatment with a cellulose nanofiber membrane $\left(\right.$ Nanoskin $\left.{ }^{\circledR}\right)$ was instituted since there was minimal wound healing and the wound had a serosanguinous secretion. The dog required sedation $(0.5 \mathrm{mg} / \mathrm{kg}$ morphine and $0.05 \mathrm{mg} / \mathrm{kg}$ acepromazine both intramuscularly) for every bandage change as it had a naturally jumpy behavior. The total time for wound repair was 35 days, during which time the membrane and bandage were changed on days 5, 7, 11 and 13 (considering the first debridement as day one). After this period of time, the wound remained without the membrane and daily cleaning was performed at home by the owner. The wound was evaluated at the hospital on days $18,22,25$ and 35.

On the $7^{\text {th }}$ day after beginning the treatment, a hemorrhagic crust covered the wound with areas of granulation tissue with a discrete purulent discharge (Figures 1D and 1E). Wound contraction was also noted, and on the following days the wound remained similar in appearance. On the $18^{\text {th }}$ day, wound width and depth had increased. Once granulation tissue reached the level of the epidermis surrounding the wound, the membrane was not used anymore. From this day forward, the wound was cleaned daily with Lactated Ringer's solution, and no bandage was used. On day 22, a thin serous crust on the margins was observed, and the wound was greatly contracted wound and filled by granulation tissue (Figure 1F), characteristics that were not seen upon return on day 35 due to a great area of epithelization with a small crust. The last visit was on day 45 when only a scar was observed.

\section{Discussion}

In the present cases, the membrane was well tolerated by tissues of the wound, in which all wound repair phases were macroscopically observed as previously described (PAVLETIC, 1999; HOSGOOD, 2006), with the exception of the granulation phase which will be discussed further. Pre-clinical studies evaluating biodegradable membranes have shown their potential in wound repair (VATANKHAH et al., 2014). Additionally, Pereira et al. (2013) used the same membrane in a similar study with two felines and one canine in which they observed good wound repair with greater comfort for the patients. Indeed, we also observed the bandage changes to be comfortable for the patients during treatment.

We believe the membrane aided wound repair in both cases as the wounds presented with characteristics of difficult repair as described by Pavletic (1999): the wounds were bite wounds and consequently contaminated, the wounds were deep and both were located on limbs, places of greater movement. Another important aspect was the small amount of muscles on the wound bed, since cutaneous blood vessels for wound repair are greatly dependent on vessels of the adjacent muscles (PAVLETIC, 1999).

In order to evaluate the performance of the membrane, repair phases should be addressed. During the inflammation/debridement phase, platelet activation occurs to form the blood clot which incorporates chemotactic proteins for neutrophils and fibronectin forming the provisional matrix (HOSGOOD, 2006). In this process, the membrane may provide the support matrix for the formation of the blood clot and the migration 
and activation of leucocytes. It is well known that in this phase, the composition and structure of a given membrane are also capable of protecting exposed nerves, resulting in immediate pain relief with greater comfort for the patient, in addition to a hemostatic effect, decrease in exudate and protection against microorganisms (PEREIRA et al., 2013; VATANKHAH et al., 2014).

During the repair phase when angiogenesis, fibroplasia, epithelization and wound contraction occur, the membrane structure can provide support for the migration and formation of new vessels as well as proliferation and adhesion of fibroblasts, which can shorten the time needed for granulation tissue formation (VATANKHAH et al., 2014). Granulation tissue is essential for total wound repair as it is the physical and biological protection of the wound and provides the surface for epithelization, which is characterized by the migration of epithelial cells from the wound margins, following the proliferation of basal cells (HEDLUND, 2008). It is known that the membranes can stimulate these processes (VATANKHAH et al., 2014) and, as early formation of granulation tissue was noted in these cases, we believe that the membrane shortens the time needed by efficiently supporting wound repair.

A remarkable aspect needing further study was the formation of exuberant granulation tissue in the first dog, which made surgical debridement necessary at four different times. Exuberant granulation tissue is quite common in equines, mainly on limb wounds. Many aspects that may stimulate the formation of exuberant granulation tissue can be cited, including bandages keeping a humid and hot environment, constant irritation with exudate, chronic inflammation and a few predisposed places (WILMINK; VAN WEEREN, 2004). We believe that the membrane can favor the formation of granulation tissue (PEREIRA et al., 2013; OLYVEIRA et al., 2014) as previously discussed, which may have also favored the exuberant type when used on already developed granulation tissue. To the best of the authors' knowledge, exuberant granulation tissue has not been reported in dogs, which is reinforced by the fact that, after stopping the use of the membrane, this tissue was not observed and repair progressed uneventfully to epithelization. Another important aspect is wound location. In this study, the wounds were located on the limb and close to a joint, and thus places where movement is frequent. It is well known that in equines, too much movement may predispose wounds to form excessive granulation tissue (WILMINK; VAN WEEREN, 2004).

Given the observations of the first dog, we decided that when granulation tissue in the second dog reached the level of the epidermis margins around the wound, the membrane would not be used anymore. In this animal, exuberant granulation tissue was not observed. Biologic and bioactive membranes are indicated for wounds in inflammatory and repair phases as they act on fibroplasia in extracellular matrix formation, in addition to attracting cells for repair and stimulating the differentiation of some cell types (HOSGOOD, 2006; DERNELL, 2006). Furthermore, we believe that the membrane will be useful in shortening the time needed for the formation of granulation tissue in animals that present a delayed healing process, like cats, mainly in the beginning of the repair (BOHLING et al., 2004).

Figure 2 shows the decrease in wound size during the time needed for wound repair, in order to analyze the repair by focusing on wound contraction. The greater decrease in wound size in animal 1 occurred between days 1 and 6, probably due to constant cleaning of the wound, fighting against infection with oral antibiotics and using the membrane. The plateau observed between days 26 and 34 shows a period of time when no contraction was observed, probably related to the exuberant granulation tissue and the consequent debridement processes that were necessary. For animal 2, the figure shows a great initial decrease in width, but no alteration in depth and height, probably due to the absence of granulation tissue. A progressive 
decrease was observed on days 11 and 13, when granulation tissue formation was observed. On day 18 , width and height were a little greater, probably related to a separation of the wound margins by the formation of granulation tissue deep in the wound, when the level of the granulation tissue reached the borders of the surrounding epidermis. Upon this event, epithelium formed on the wound as demonstrated by a great decrease both in width and height.

Figure 2. Image representing the decrease in wound size of both animals treated at HVT-UFV, Viçosa, 2014, with the use of a nanofiber polymer membrane. A: Graphic showing measurements of height (longitudinal to the body's long axis) and width (transversal to the body's long axis) of the wound in case 1, related to the days of clinical examination, showing its decrease in size during the treatment. B. Graphic showing measurements of height, width and depth of the wound in case 2, related to the days of clinical examination, showing its decrease in size during the treatment.

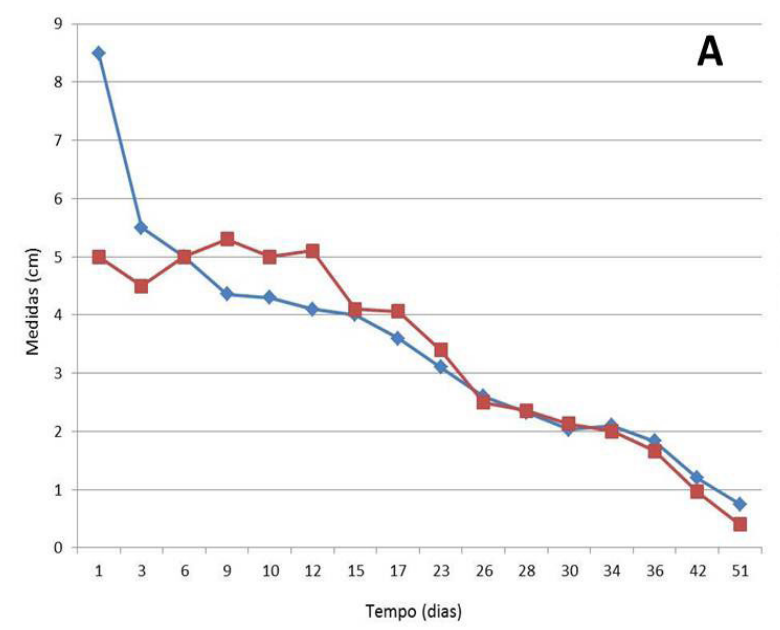

The membrane used in the present work is indicated for human wounds in any phase of the repair process, however, there are few studies in dogs. Based on our report, we suggest a tendency of the membrane to stimulate the formation of granulation tissue. However, further studies with a greater number of treated animals should be performed before definitively concluding that this membrane is capable of accelerating wound repair in dogs.

\section{Conclusion}

The cellulose nanofiber membrane proved to be a viable and promising therapeutic option for wound repair in dogs, as there was efficient wound repair which followed known wound healing stages.

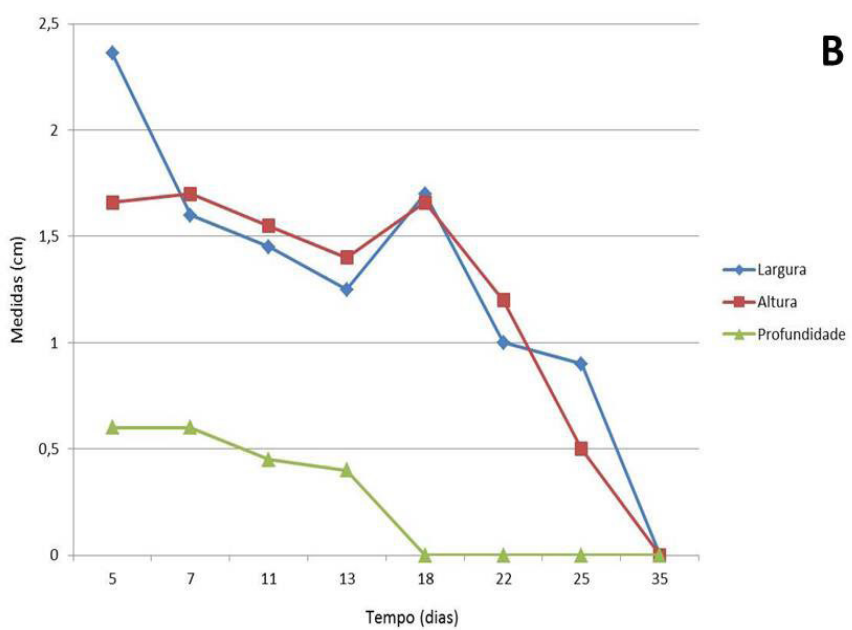

These reported cases suggest that other studies are needed to evaluate the activity of the membrane on the formation of granulation tissue in dogs. There may be better wound repair results if the membrane is used until granulation tissue forms on the wound bed and then discontinued, since its continuous use may favor the formation of exuberant granulation tissue.

\section{Acknowledgements}

The authors thank Prof. Dr. Pierre Basmaji, former professor at IFSC-USP and now researcher of the Instituto de Pesquisa e Desenvolvimento da INNOVATECS, for supplying the membranes and thank CAPES, FAPEMIG and CNPq for support. 


\section{References}

ARIAS, M. V. B.; BATTAGLIA, L. A.; AIELLO, G.; CARVALHO, T. T.; FREITAS, J. C. Identificação da suscetibilidade antimicrobiana de bactérias isolada de cães e gatos com feridas traumáticas contaminadas e infectadas. Semina: Ciências Agrárias, Londrina, v. 29, n. 4, p. 861-874, 2008.

ARRUDA, G. G. A.; BARBO, M. L. P.; DUEK, E. A. R. Membranas de PLGA como curativos cutâneos. In: CONGRESSO LATINO AMERICANO DE ÓRGÃOS ARTIFICIAIS E BIOMATERIAIS, 6., 2010, Gramado. Anais... Gramado: Slabo, 2010. p. 1-2.

BOHLING, M. W.; HENDERSON, R. A.; SWAIM, S. F.; KINCAID, S. A.; WRIGHT, J. C. Cutaneous wound healing in the cat: a macroscopic description and comparison with cutaneous wound healing in the dog. Veterinary Surgery, Auburn, v. 33, n. 6, p. 579-587, 2004.

DERNELL, W. S. Initial wound management. Veterinary Clinics of North America Small Animal Practice, Fort Collins, v. 36, n. 4, p. 713-738, 2006.

GURTNER, G. C.; WERNER, S.; BARRANDON, Y.; LONGAKER, M. T. Review article wound repair and regeneration. Nature, London, v. 453, n. 7193, p. 314321,2008 .

HEDLUND, C. H. Cirurgia do sistema tegumentar. In: FOSSUM, T. W. Cirurgia de pequenos animais. $3^{\text {th }}$ ed. Rio de Janeiro: Elsevier, 2008. p. 159-259.

HOSGOOD, G. Stages of wound healing and their clinical relevance. Veterinary Clinics of North America Small Animal Practice, Baton Rouge, v. 36, n. 4, p. 667685, 2006.
ISAAC, C.; LADEIRA, P. R. S.; RÊGO, F. M. P.; ALDUNATE, J. C. B.; FERREIRA, M. C. Processo de cura das feridas: cicatrização fisiológica. Revista de Medicina, São Paulo, v. 89, n. 3-4, p. 125-131, 2010.

KONWARH, R.; KARAK, N.; MISRA, M. Electrospun cellulose acetate nanofibers: The present status and gamut of biotechnological applications. Biotechnology Advances, India, v. 31, n. 4, p. 421-437, 2013.

OLYVEIRA, G. M.; SANTOS, M. L.; DALTRO, P. B.; BASMAJI, P.; DALTRO, G. C.; GUASTALDI, A. C. Bacterial cellulose/chondroitin sulfate for dental materials scaffolds. Journal of Biomaterials and Tissue Engineering, Brazil, v. 4, n. 4, p. 1-5, 2014.

PAVLETIC, M. M. Basic principles of wound healing. In: PAVLETIC, M. M. Atlas of small animal reconstructive surgery. $2^{\text {th }}$ ed. Philadelphia: Saunders Company, 1999. p. 11-17.

PEREIRA, A. C.; GALLINA, M. F.; GALlO, G.; LUCAS, F. A.; ANDRADE, A. L.; LARANJEIRA, M. G. Uso de membrana de nanofibras de polímeros biodegradáveis no tratamento de feridas cutâneas Relato de 3 casos. In: CONGRESSO BRASILEIRO DA ANCLIPEVA, 35., 2013, Goiânia. Anais... Goiânia: Universidade Federal de Goiás, 2013. p. 202-204.

VATANKHAH, E.; PRABHAKARAN, M. P.; JIN, G.; MOBARAKEH, L. G.; RAMAKRISHNA, S. Development of nanofibrous cellulose acetate/gelatin skin substitutes for variety wound treatment applications. Journal of Biomaterials Applications, Singapora, v. 28, n. 6, p. 909-921, 2014.

WILMINK, J. M.; VAN WEEREN, P. R. Differences in wound healing between horses and ponies: Application of research results to the clinical approach of equine wounds. Clinical Techniques in Equine Practice, The Netherlands, v. 3, n. 2, p. 123-133, 2004. 